\title{
ANALISIS KINERJA KEUANGAN PT BANK RAKYAT INDONESIA (PERSERO), TBK
}

\author{
${ }^{1)}$ Sarida Sirait, ${ }^{2)}$ Henry Dunan Pardede \\ ${ }^{2}$ Komputerisasi Akuntansi, Politeknik Bisnis Indonesia, \\ E-mail : saridasrt@gmail.com \\ ${ }^{2}$ Keuangan Perbankan, Politeknik Bisnis Indonesia, \\ E-mail : henrydunanpardede031@gmail.com
}

\begin{abstract}
The Bank's Financial Performance Appraisal Method continues to evolve along with developments. This study aims to compare the level of financial performance of PT Bank Rakyat Indonesia (Persero) Tbk. in the period of Quarter I 2019 - Quarter II of 2020. The Bank's Financial Performance Level is measured through several assessments. These assessments include ratio assessments (ROA, ROE, NIM, BOPO). This research is a descriptive study with a quantitative approach. The subject of this research is the financial statements of PT Bank Rakyat Indonesia Tbk. (Persero). The object used in this research is the financial statements of PT Bank Rakyat Indonesia Tbk. (Persero) Quarter I 2019 - Quarter II 2020. The data collection technique in this study is by downloading financial reports from the official website of PT Bank Rakyat Indonesia Tbk. (Persero). The analysis technique used is the ratio assessment. The results of this study note that the Financial Performance Assessment of PT Bank Rakyat Indonesia Tbk. (Persero) with this ratio approach shows a continuing downward trend.
\end{abstract}

Keywords: Financial Performance, Ratio

\section{PENDAHULUAN}

\section{Latar Belakang}

Bank merupakan salah satu lembaga yang berperan sebagai perantara keuangan (Financial Intermediary) antara pihak yang memiliki dana dan pihak yang memerlukan dana . Menurut Undang-Undang RI tentang Perbankan nomor 10 tahun 1998 bank adalah badan usaha yang menghimpun dana dari masyarakat dalam bentuk simpanan dan menyalurkannya kepada masyarakat dalam bentuk kredit dan atau bentuk-bentuk lainnya dalam rangka meningkatkan taraf hidup rakyat banyak. Bank mempunyai fungsi sangat strategis dalam pembangunan nasional, mengingat fungsi utamanya sebagai penghimpun dana penyalur dana, dengan tujuan menunjang pelaksanaan pembangunan nasional dalam rangka meningkatkan pemerataan pertumbuhan ekonomi, dan stabilitas nasional ke arah peningkatan kesejahteraan rakyat banyak. Bisnis perbankan merupakan usaha yang sangat mengandalkan kepercayaan, yaitu kepercayaan masyarakat sebagai pengguna jasa perbankan. Sedikit saja isu berkaitan dengan kondisi bank yang tidak sehat, maka masyarakat akan berbondong-bondong mengambil dana yang tersimpan dalam bank tersebut, sehingga akan lebih memperburuk kondisi bank tersebut.

Salah satu hal yang ikut serta menunjang keberhasilan pembangunan ekonomi adalah stabil atau sehatnya sektor perbankan. Sektor perbankan merupakan jantung dalam sistem perekonomian sebuah negara dan sebagai alat dalam pelaksanaan kebijakan moneter.

Gambar.1.1. Grafik Laba PT.Bank Rakyat Indonesia. 


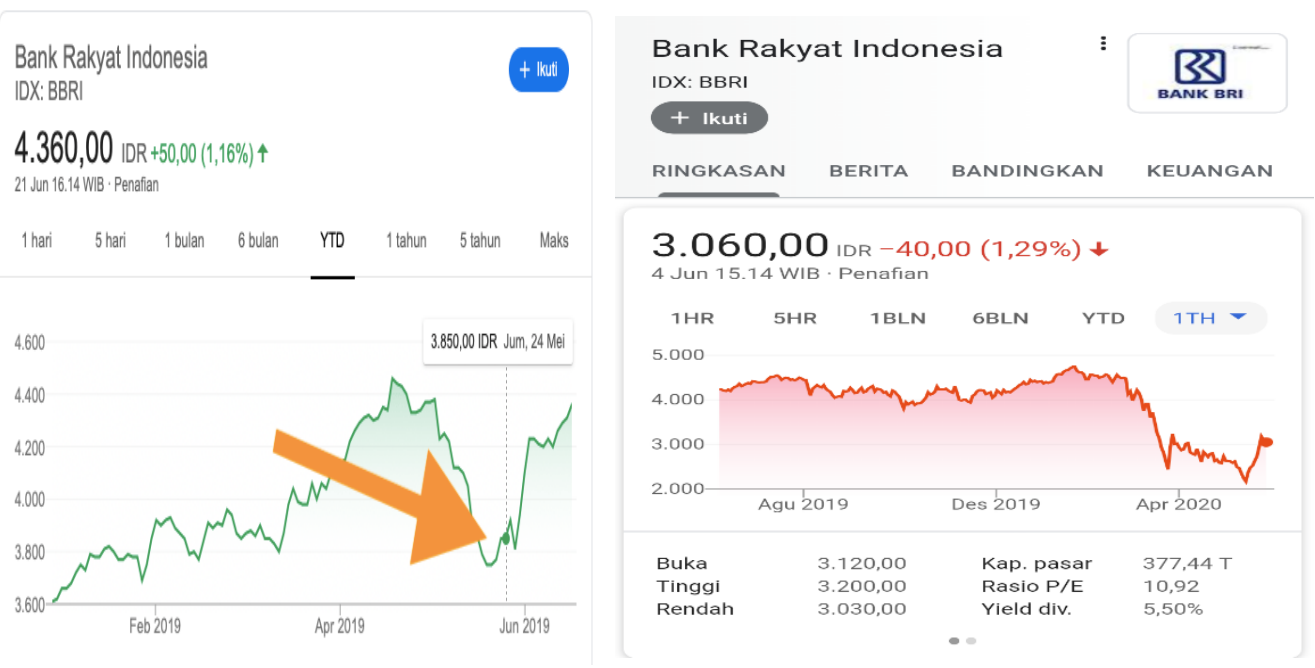

Namun jika dilihat grafik laba pada gambar diatas PT.Bank Rakyat Indonesia (PERSERO) Tbk. memperoleh laba yang tidak stabil dan bahkan lebih cenderung mengalami penurunan. Tahun 2019 adalah tahun politik yang sangat menentukan kondisi perekonomian Indonesia lima tahun kedepan. Ditambah lagi di penghujung akhir tahun 2019 adanya pandemi Covid-19 yang menyebar keseluruh dunia secara silih berganti. Berawal dari kota Wuhan Virus Covid-19 ini mulai menyebar ke Jepang, Korea dan Negara Singapura yang paling dekat dengan Indonesia. Kemudian isu-isu Virus Covid-19 mulai terdengar di Indonesia pada pertengahan bulan Februari 2020, dan pada awal bulan Maret 2020 Presiden Jokowidodo untuk pertama kalinya mengumumkan dua pasien positif virus corona. Sejak saat itu pemerintah melakukan beberapa tindakan guna untuk memutus rantai virus corona dengan cara melakukan PSBB (Pembatasan Sosial Berskala Besar), meliburkan seluruh sekolah dan para karyawan ataupun pegawai yang bekerja untuk tetap berada didalam rumah guna mencegah penyebaran Covid-19. Dikarenakan banyaknya karyawan yang dirumahkan untuk beberapa waktu kedepan membuat keuangan juga semakin sulit. Daya beli masyarakat pun menurun ditambah lagi dengan adanya pembatasan aktivitas ekonomi demi menekan virus corona. Akibatnya banyak pelaku usaha yang menunda pengajuan kredit pada perbankan.
Berdasarkan

No.11/POJK.03/2020 tentang Stimulus Perekonomian Nasional Sebagai Kebijakan Countercyclical Dampak Penyebaran Corona Virus Disease 2019 (POJK Stimulus Dampak Covid-19) yang memerintahkan perbankan untuk memberikan relaksasi keringanan bagi para debiturnya dengan cara melakukan penurunan suku bunga, perpanjangan jangka waktu, pengurangan tunggakan pokok, pengurangan tunggakan bunga, penambahan fasilitas kredit/pembiayaan, dan/atau konversi kredit/pembiayaan menjadi penyertaan modal sementara.

\section{Pengertian Kesehatan Bank}

Secara sederhana dapat dikatakan bahwa bank yang sehat adalah bank yang dapat menjalankan fungsi-fungsinya dengan baik. Menurut [1], bank yang sehat adalah bank yang dapat menjaga dan memelihara kepercayaan masyarakat, dapat menjalankan fungsi intermediasi, dapat membantu kelancaran lalu lintas pembayaran serta dapat digunakan oleh pemerintah dalam melaksanakan berbagai kebijakannya, terutama kebijakan moneter. Dengan menjalankan fungsi-fungsi tersebut diharapkan dapat memberikan pelayanan yang baik kepada masyarakat serta bermanfaat bagi perekonomian secara keseluruhan. Untuk dapat menjalankan fungsinya dengan baik, bank harus mempunyai modal yang cukup, menjaga kualitas asetnya dengan baik, dikelola dengan baik dan dioperasikan berdasarkan prinsip kehati-hatian, 
menghasilkan keuntungan yang cukup untuk mempertahankan kelangsungan usahanya, serta memelihara likuiditasnya sehingga dapat memenuhi kewajibannya setiap saat. Selain itu, suatu bank harus senantiasa memenuhi berbagai ketentuan dan aturan yang telah ditetapkan, yang pada dasarnya berupa berbagai ketentuan yang mengacu pada prinsip kehati-hatian di bidang perbankan [2].

Berdasarkan BAB I Pasal 2 Ayat (1) Peraturan Otoritas Jasa Keuangan Nomor 4/POJK.03/2016 tentang Penilaian Kesehatan Bank Umum yang berbunyi bahwa Bank wajib memelihara dan/atau meningkatkan Tingkat Kesehatan Bank dengan menerapkan prinsip kehati-hatian dan manajemen risiko dalam melaksanakan kegiatan usaha. Sedangkan Pasal 2 Ayat (3) yang berbunyi bahwa Bank wajib melakukan penilaian Tingkat Kesehatan Bank dengan menggunakan pendekatan risiko (Risk-based Bank Rating) baik secara individu maupun secara konsolidasi.

Menurut [3] tentang Mekanisme Penilaian Tingkat Kesehatan Bank Secara Individu yang berbunyi Bank wajib melakukan penilaian Tingkat Kesehatan Bank secara individu dengan menggunakan pendekatan risiko (Risk-based Bank Rating) sebagaimana dimaksud dalam Pasal 2 Ayat (3), dengan cakupan penilaian terhadap faktorfaktor sebagai berikut :
a. Profil Risiko (Risk Profile);
b. Good Corporate Governance (GCG);
c. Rentabilitas (Earning); dan
d. Permodalan (Capital).

Dalam hal ini penulis menilai kinerja keuangan atau kesehatan pada PT.Bank Rakyat Indonesia (PERSERO) Tbk. dengan menggunakan rasio rentabilitas atau earning performance. Dimana pada Pasal 7 Ayat (3) berbunyi Kewajiban penilaian terhadap faktor rentabilitas (earnings) sebagaimana dimaksud dalam Pasal 6 huruf c meliputi penilaian terhadap kinerja rentabilitas (Earnings), sumber-sumber rentabilitas (earnings), dan kesinambungan.

\section{Pengukuran Kinerja Keuangan}

Pengukuran kinerja (performing measurement) ialah kualifikasi \& efisiensi serta efektivitas perusahaan di dalam pengoperasian bisnis perusahaan selama periode akuntansi. Menurut [4] Penilaian kinerja adalah "proses penilaian prestasi perusahaan secara sistematik berdasarkan pekerjaan yang ditugas kan".

Menurut [5] mengatakan bahwa tujuan dari adanya pengukuran kinerja keuangan perusahaan ialah :

- Mengetahui tingkat likuiditas. Likuiditas ini menunjukkan sebuah kemampuan suatu perusahaan guna memenuhi kewajiban keuangan yang seharusnya segera diselesaikan pada waktu ditagih.

- Mengetahui tingkat solvabilitas. Solvabilitas ini menunjukkan sebuah kemampuan perusahaan guna memenuhi kewajiban keuangannya jika perusahaan tersebut dilikuidasi, baik keuangan dalam jangka pendek ataupun jangka panjang.

- Mengetahui tingkat rentabilitas. Rentabilitas atau yang sering dikenal dengan profitabilitas ini menunjukkan sebuah kemampuan perusahaan guna menghasilkan profit selama periode tertentu.

- Mengetahui tingkat stabilitas. Stabilitas ini menunjukkan sebuah kemampuan perusahaan guna melakukan usahanya secara stabil, yang diukur menggunakan pertimbangan kemampuan perusahaan guna membayar hutang - hutangnya serta membayarkan beban bunga dari hutang hutangnya secara tepat pada waktunya.

\section{Analisis Kinerja Keuangan}

Kinerja keuangan bisa dinilai dengan sejumlah alat analisis. Berikut ini jenis-jenis analisis keuangan yang umum dipakai oleh berbagai perusahaan, [6].

1. Analisis Perbandingan Laporan Keuangan, adalah teknik analisis dengan cara membandingkan sebuah laporan keuangan dalam dua periode atau lebih dengan cara menunjukkan perubahan, baik pada jumlah (absolut) ataupun dalam persentase (relatif).

2. Analisis Tren atau tendensi posisi, adalah teknik analisis guna mengetahui tendensi kondisi keuangan apakah sedang menunjukkan kenaikan atau malah penurunan. 
3. Analisis Persentase per-Komponen (common size), adalah teknik analisis guna mengetahui persentase investasi di masing - masing aktiva terhadap keseluruhan atau jumlah total aktiva maupun utang.

4. Analisis Sumber \& Penggunaan Modal Kerja, adalah teknik analisis guna mengetahui besarnya sumber dana dan penggunaan modal kerja melewati dua periode waktu yang sudah dibandingkan.

5. Analisis Sumber \& Penggunaan Kas, adalah teknik analisis guna mengetahui keadaan kas disertai sebab dari terjadinya perubahan kas dalam suatu periode waktu tertentu.

6. Analisis Rasio Keuangan, adalah teknik analisis keuangan guna mengetahui hubungan di antara pos - pos tertentu dalam neraca ataupun laporan laba rugi baik secara individu ataupun secara simultan.

7. Analisis Perubahan Laba Kotor, adalah teknik analisis guna mengetahui posisi laba dan sebab - sebab terjadinya dari perubahan laba.

8. Analisis Break Even, adalah teknik analisis guna mengetahui tingkat

\section{METODE}

\subsection{Metode dan Teknik Analisis}

Penelitian ini menggunakan tipe penelitian deskriptif dengan pendekatan kuantitatif. Sampel dalam penelitian ini adalah Laporan Keuangan Triwulan I, II, III, IV tahun 2019 dan Triwulan I dan II tahun 2020. Dalam penelitian ini menggunakan 2 cara yaitu, Dokumentasi dan Kepustakaan (Library Research).

Teknik analisis yang digunakan dalam penelitian ini adalah dengan menggunakan rasio untuk menilai tingkat kinerja keuangan pada PT. Bank Rakyat Indonesia (PERSERO) Tbk. dengan mengacu kepada Surat Edaran Otoritas Jasa Keuangan Nomor 14/SEOJK.03/2017 tentang Penilaian Tingkat Kesehatan Bank Umum, karena adanya variabel yang akan ditelaah hubungannya

\section{HASIL DAN PEMBAHASAN Penilaian Rasio}

penjualan yang harus dicapai supaya perusahaan tidak akan mengalami kerugian.

\section{Pengertian Laporan Keuangan}

Menurut [7] pengertian laporan keuangan adalah laporan yang menunjukkan kondisi keuangan perusahaan saat ini atau periode kedepannya. Maksud dan tujuan laporan keuangan menunjukkan kondisi keuangan perusahaan.

Menurut [8] bahwa pengertian laporan keuangan terdiri dari neraca dan suatu perhitungan laba-rugi serta laporan mengenai perubahan ekuitas. Neraca tersebut menunjukkan atau menggambarkan jumlah suatu aset, kewajiban dan juga mengenai ekuitas dari suatu perusahaan pada tanggal tertentu.

Menurut Ikatan Akuntan Indonesia bahwa definisi mengenai laporan keuangan terdiri dari proses laporan keuangan pada umumnya terdiri dari neraca, laporan laba rugi, laporan perubahan ekuitas, laporan posisi keuangan, catatan dan laporan lain serta materi akan penjelasan yang merupakan bagian integral dari laporan keuangan.ungan rentabilitas (earnings'sustainability) Bank.

Menurut [9] tujuan laporan keuangan adalah untuk menyajikan gambaran secara terstruktur, faktual, dan akurat mengenai fakta-fakta secara hubungan variabel yang diteliti. Dalam penelitian ini, metode deskriptif digunakan untuk menjelaskan tentang mengukur kesehatan Bank Rakyat Indonesia (PERSERO) Tbk. dengan menggunakan Surat Edaran Otoritas Jasa Keuangan Nomor 14/SEOJK.03/2017 tentang Penilaian Tingkat Kesehatan Bank Umum Rasio yang digunakan adalah :
a. Return On Assets (ROA)
b. Net Interest Margin (NIM)
c. Return On Equity (ROE)
d. Beban Operasional terhadap Pendapatan Operasional (BOPO)

Rasio yang digunakan untuk melihat kinerja keuangan PT.Bank Rakyat Indonesia 
DOI 10.37600/ekbi.v3i2.197

(PERSERO) Tbk adalah sebagai berikut :

a. ROA (Return On Asset)

Return On Assets (ROA) digunakan untuk mengukur kemampuan manajemen bank dalam memperoleh keuntungan dari aset secara keseluruhan. Semakin besar Return On
Assets (ROA) PT.Bank Rakyat Indonesia (PERSERO) Tbk, maka semakin baik tingkat keuntungan bank dan semakin baik posisi bank dari segi penggunaan asetnya. Untuk mendapatkan hasil dari Return On Asset dapat digunakan rumus sebagai berikut :

$$
\frac{\text { Laba Setelah Pajak }}{\text { Total Aset }} \times 100
$$

Tabel 1. Return On Asset PT.Bank Rakyat Indonesia (PERSERO) Tbk (Dalam Jutaan Rupiah)

\begin{tabular}{lccc}
\hline \multicolumn{1}{c}{ Triwulan } & $\begin{array}{c}\text { Laba Setelah } \\
\text { Pajak }\end{array}$ & Total Aset & $\begin{array}{c}\text { Return On } \\
\text { Asset (\%) }\end{array}$ \\
\hline I Tahun 2019 & Rp10.153.318 & Rp1.279.860.648 & 0.8 \\
II Tahun 2019 & Rp19.860.702 & Rp1.288.195.552 & 1.5 \\
III Tahun 2019 & Rp31.056.525 & Rp1.305.666.548 & 2.4 \\
IV Tahun 2019 & Rp43.364.053 & Rp1.416.758.840 & 3.1 \\
I Tahun 2020 & Rp10.155.705 & Rp1.358.978.917 & 0.8 \\
II Tahun 2020 & Rp15.539.443 & Rp1.387.759.264 & 1.1 \\
\hline
\end{tabular}

\section{Gambar 1.}

Grafik Perkembangan Return On Assets (ROA)

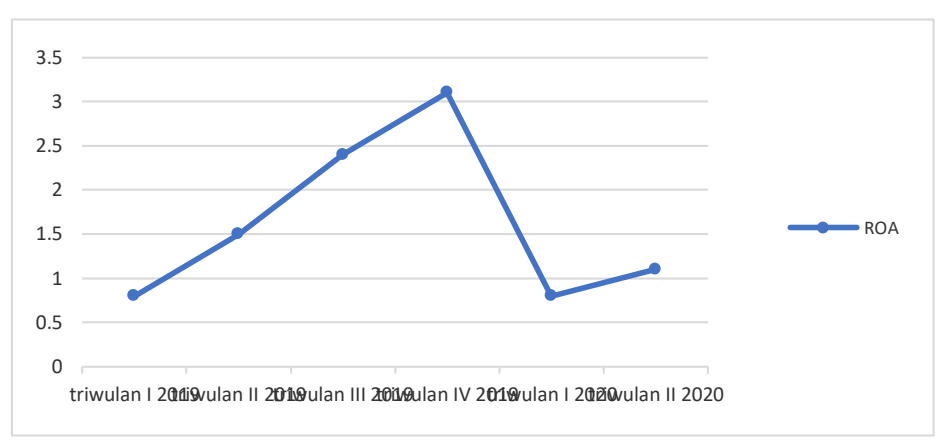

bank BRI

Berdasarkan perhitungan Return On Assets pada triwulan I tahun 2019 tingkat rasio adalah sebesar $0.8 \%$. Artinya PT.Bank Rakyat Indonesia (PERSERO) Tbk. dalam setiap rupiah kemampuan bank untuk menghasilkan laba dengan aset sebesar Rp0.8 atau dari total aset $\mathrm{Rp} 1.279 .860 .648$,- bank hanya mampu menghasilkan laba sebesar Rp 10.153.318,pada triwulan ini melambatnya pertumbuhan laba BRI karena terbebani oleh Danareksa Sekuritas yang baru saja di akuisisi. Tidak hanya Danareksa Sekuritas, anak usaha lainnya yaitu BRI Agro dan BRI Syariah juga sedang dalam tahap pembenahan. Pada triwulan ke-II sampai triwulan ke-IV laba mengalami sedikit peningkatan menjadi 1.5\% pada triwulan ke-II tahun 2019, 2.4\% pada triwulan ke-III tahun 2019 dan 3.1\% pada triwulan ke-IV tahun 2019. Namun pada triwulan ke-I tahun 2020 laba dengan aset yang dihasilkan oleh bank menurun kembali menjadi $0.8 \%$ dan pada triwulan ke-II tahun 2020 laba yang dicapai oleh bank BRI hanya $1.1 \%$. Hal ini disebabkan karena pada akhir tahun 2019 munculnya virus Covid-19 yang mengguncang dunia dan menyebabkan perekonomian dunia menjadi menurun. Ditambah lagi dengan adanya restrukturisasi yang dilakukan oleh Bank Indonesia. Ditambah lagi Covid-19 membuat risiko kredit semakin tinggi yang akan menjadi 
Return On Equity (ROE) digunakan untuk menunjukkan efisiensi penggunaan modal sendiri. Semakin besar Return On Equity (ROE) PT.Bank Rakyat Indonesia

$$
\frac{\text { Laba Setelah Pajak }}{\text { Total Ekuitas }} \times 100
$$

Tabel 2

Return On Equity PT.Bank Rakyat Indonesia (PERSERO) Tbk (Dalam Jutaan Rupiah)

\begin{tabular}{lcccc}
\hline \multicolumn{1}{c}{ Triwulan } & $\begin{array}{c}\text { Laba Setelah } \\
\text { Pajak }\end{array}$ & Ekuitas & $\begin{array}{c}\text { Return On } \\
\text { Equity (\%) }\end{array}$ \\
\hline I & Tahun 2019 & Rp 8.196 .449 & Rp194.911.484 & 4 \\
II Tahun 2019 & Rp16.162.860 & Rp190.840.791 & 8 \\
III Tahun 2019 & Rp24.803.424 & Rp199.539.777 & 12 \\
IV Tahun 2019 & Rp34.413.825 & Rp208.784.336 & 16 \\
I Tahun 2020 & Rp 8.169.902 & Rp179.638.893 & 5 \\
II Tahun 2020 & Rp10.201.042 & Rp187.835.213 & 5 \\
\hline
\end{tabular}

Gambar 2.

Grafik Perkembangan Return On Equity (ROE)

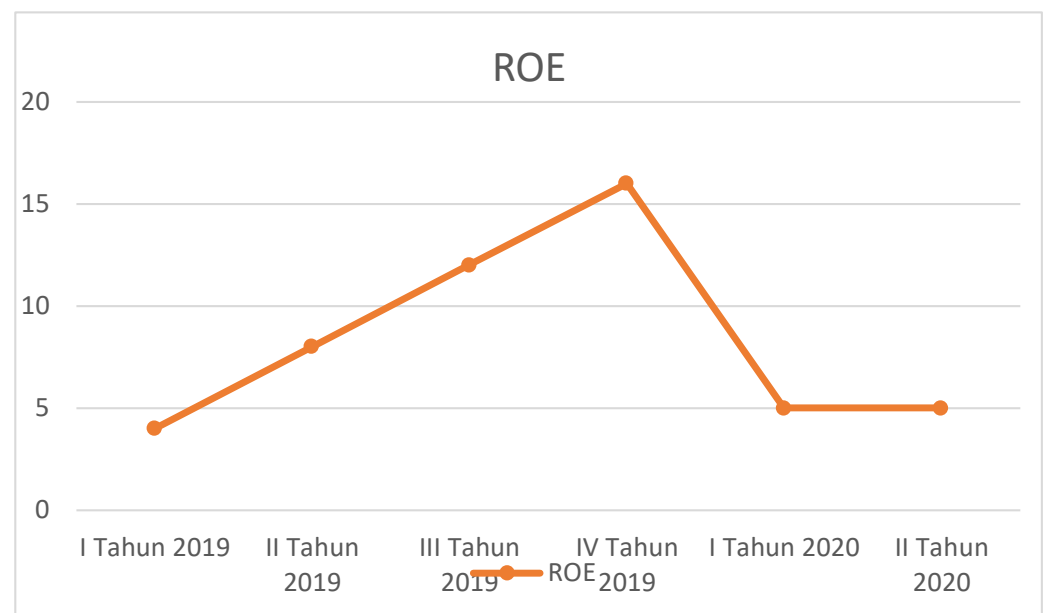

Berdasarkan perhitungan Return On Equity (ROE) pada triwulan ke-I tahun 2019 tingkat rasionya sebesar $4 \%$ dan mengalami peningkatan pada triwulan ke-II tahun 2019 sebesar $8 \%$, pada triwulan ke-III $12 \%$ dan pada triwulan ke-IV tahun 2019 menjadi 16\%. Namun memasuki triwulan ke-I dan ke-II pada tahun 2020 ROE PT.BRI (PERSERO) Tbk mengalami penurunan yang begitu signifikan menjadi 5\%. ROE mengalami penurunan yang begitu signifikan dari tahun 2019 disebabkan karena pada saat itu muncul isu-isu mengenai Covid-19 yang mulai meluas dari Wuhan ke
Jepang, Korea dan Negara Singapura yang paling dekat dengan Indonesia. Hal ini menyebabkan IHSG Indonesia mengalami penurunan. Penurunan ini tidak lepas dari para investor yang melihat bahwa pemerintah Indonesia pada saat itu belum serius untuk menangani Covid-19, sehingga krisis kesehatan terjadi dan membuat para investor lebih memilih menarik dananya dari pasar modal yang membuat harga saham mengalami penurunan. Selain menurun nya harga saham ataupun ekuitas, ROE mengalami penurunan disebabkan laba bersih yang menurun. Laba 
bersih PT.Bank Rakyat Indonesia (PERSERO) Tbk, menurun karena adanya tekanan pada pendapatan bunga dan juga tingginya restrukturisasi kredit akibat pandemi Covid-19, khususnya di segmen mikro dan perlambatan pertumbuhan kredit juga mendorong penurunan laba. c. NIM (Net Interest Margin)

Net Interest Margin (NIM) adalah rasio yang digunakan untuk menganalisis seberapa besar pendapatan bunga bersih dibandingkan dengan aset produktif. Untuk mendapatkan hasil dari Net Interest Margin dapat digunakan rumus sebagai berikut :

$$
\frac{\text { Pendapatan Bunga Bersih }}{\text { Total Aset Produktif }} \times 100
$$

Tabel 3

Net Interest Margin PT.Bank Rakyat Indonesia (PERSERO) Tbk (Dalam Jutaan Rupiah)

\begin{tabular}{lccc}
\hline \multicolumn{1}{c}{ Triwulan } & $\begin{array}{c}\text { Pendapatan } \\
\text { Bunga Bersih }\end{array}$ & Aset Produktif & $\begin{array}{c}\text { Net Interest } \\
\text { Margin }\end{array}$ \\
\hline I Tahun 2019 & Rp19.625.759 & Rp1.114.083.979 & $2 \%$ \\
II Tahun 2019 & Rp40.042.630 & Rp1.122.455.377 & $4 \%$ \\
III Tahun 2019 & Rp60.869.517 & Rp1.150.005.377 & $5 \%$ \\
IV Tahun 2019 & $\mathrm{Rp} 82.718 .033$ & $\mathrm{Rp} 1.248 .646 .352$ & $7 \%$ \\
I Tahun 2020 & $\mathrm{Rp} 21.526 .092$ & $\mathrm{Rp} 1.198 .168 .530$ & $2 \%$ \\
II Tahun 2020 & $\mathrm{Rp} 37.085 .937$ & $\mathrm{Rp} 1.251 .784 .583$ & $3 \%$ \\
\hline
\end{tabular}

Gambar 3.

\section{Grafik Perkembangan Net Interest Margin (NIM)}

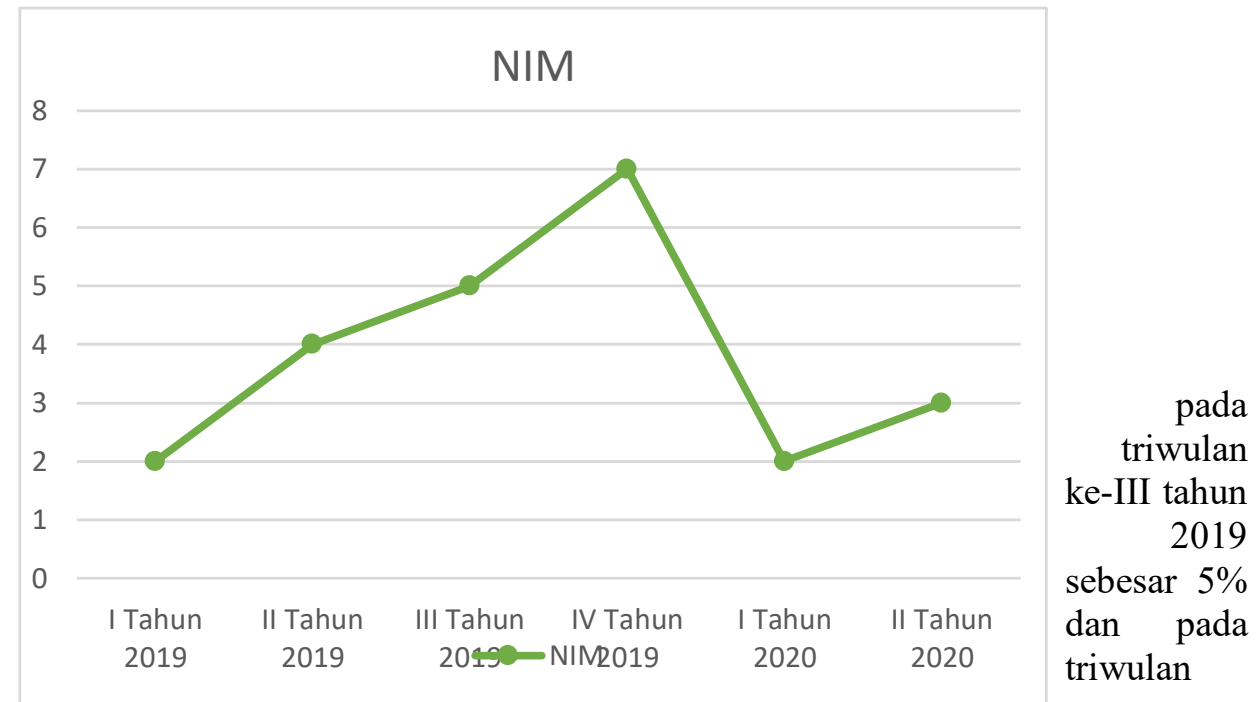

Untuk rasio NIM PT.BRI (PERSERO) Tbk triwulan ke-I tahun 2019 sebesar 2\% dan mengalami peningkatan secara bertahap pada triwulan ke-II tahun 2019 menjadi sebesar 4\%, 
ke-IV menjadi 7\%. Namun secara signifikan pada awal triwulan tahun 2020 BRI mengalami penurun kembali menjadi $2 \%$ dan pada triwulan ke-II sebesar 3\%. Pada awal periode 2019 NIM mengalami penurunan akibat dampak dari kenaikan suku bunga BI 7 Days Reverse Repo Rate sampai 6 kali. Sedangkan pada awal periode tahun 2020 hingga saat ini NIM PT.Bank Rakyat Indonesia (PERSERO) Tbk, mengalami penurunan akibat dari situasi pandemi virus corona yang memperlambat penyaluran kredit sehingga berdampak pada pendapatan bunganya. Dan pada saat bersamaan beban bunga dana simpanan yang harus dibayarkan kepada nasabah tidak mungkin dikurangi demi menjaga kecukupan likuiditas.

d. BOPO (Beban Operasional terhadap Pendapatan Operasional)

BOPO adalah rasio efesiensi bank yang mengukur beban operasional terhadap pendapatan operasional. Semakin tinggi BOPO maka semakin tidak efesiensi operasi bank. Untuk mendapatkan hasil dari BOPO dapat digunakan rumus sebagai berikut :

\section{Beban Operasional \\ $\overline{\text { Pendapatan Operasional }}$}

Tabel 4 Beban Operasional terhadap Pendapatan Operasional PT.Bank Rakyat Indonesia (PERSERO) Tbk (Dalam Jutaan Rupiah)

\begin{tabular}{cccc}
\hline Triwulan & $\begin{array}{c}\text { Total Beban } \\
\text { Operasional }\end{array}$ & $\begin{array}{c}\text { Total } \\
\text { Pendapatan } \\
\text { Operasional }\end{array}$ & BOPO $(\%)$ \\
\hline I Tahun 2019 & Rp14.896.525 & Rp25.055.054 & 59 \\
II Tahun 2019 & Rp32.254.651 & Rp52.156.052 & 62 \\
III Tahun 2019 & Rp48.710.516 & Rp79.790.300 & 61 \\
IV Tahun 2019 & Rp67.725.230 & Rp111.157.163 & 61 \\
I Tahun 2020 & Rp19.401.052 & Rp29.528.020 & 66 \\
II Tahun 2020 & Rp35.309.348 & Rp50.822.415 & 69 \\
\hline
\end{tabular}

Gambar 4.

Grafik Perkembangan BOPO

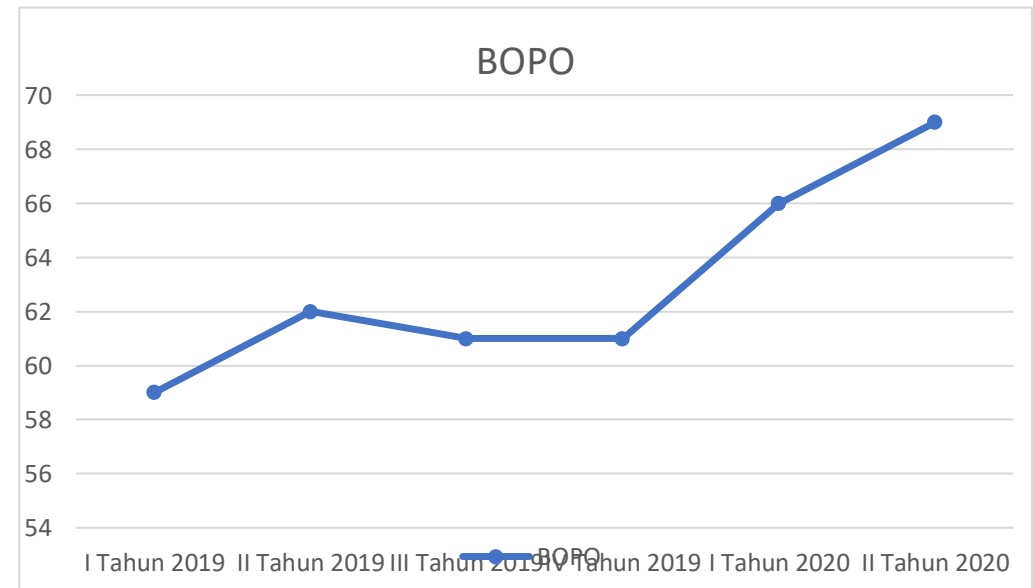

Untuk rasio BOPO PT.Bank Rakyat Indonesia (PERSERO) Tbk mengalami fluktuasi yaitu tahun 2010 sebesar 59\% dan meningkat pada triwulan ke-II pada tahun 2019 menjadi 62\% 
dan menurun kembali pada triwulan ke-III dan ke-IV pada tahun 2019 menjadi 61\%. Namun pada awal tahun 2020 rasio BOPO PT.Bank Rakyat Indonesia (PERSERO) Tbk meningkat

menjadi $66 \%$ dan pada triwulan ke-II menjadi $69 \%$. Kenaikan BOPO terjadi karena adanya tekanan pada pendapatan bunga akibat restrukturisasi kredit yang masih dilakukan perseroan sejak akhir maret 2020 guna untuk menyelamatkan UMKM terdampak Covid-19. Selain itu, BRI juga membentuk biaya pencadangan sebagai mitigasi risiko kredit akibat krisis.

Tabel 5

Rekapitulasi Hasil Perhitungan Rasio

PT.Bank Rakyat Indonesia (PERSERO) Tbk

(Dalam Jutaan Rupiah)

\begin{tabular}{ccccccc}
\hline Rasio & $\begin{array}{c}\text { Triwulan I } \\
\text { Tahun } \\
\mathbf{2 0 1 9}\end{array}$ & $\begin{array}{c}\text { Triwulan } \\
\text { II Tahun } \\
\mathbf{2 0 1 9}\end{array}$ & $\begin{array}{c}\text { Triwulan } \\
\text { III Tahun }\end{array}$ & $\begin{array}{c}\text { Triwulan } \\
\text { IV Tahun }\end{array}$ & $\begin{array}{c}\text { Triwulan } \\
\text { I Tahun } \\
\mathbf{2 0 1 9}\end{array}$ & $\begin{array}{c}\text { Triwulan } \\
\text { II Tahun } \\
\mathbf{2 0 1 9}\end{array}$ \\
\hline ROA & $0.8 \%$ & $1.5 \%$ & $2.4 \%$ & $3.1 \%$ & $0.8 \%$ & $1.1 \%$ \\
ROE & $4 \%$ & $8 \%$ & $12 \%$ & $16 \%$ & $5 \%$ & $5 \%$ \\
NIM & $2 \%$ & $4 \%$ & $5 \%$ & $7 \%$ & $2 \%$ & $3 \%$ \\
BOPO & $59 \%$ & $62 \%$ & $61 \%$ & $61 \%$ & $66 \%$ & $69 \%$
\end{tabular}

Jika dilihat dari matriks kategori, maka ROA PT.Bank Rakyat Indonesia (PERSERO) Tbk, dapat dikategorikan "tidak sehat", karena nilai rata-rata return on assets (ROA) sekitar 1.62\% atau lebih kecil dari $(<2.74 \%)$ Statistik Perbankan Indonesia. Untuk nilai Return On Equity (ROE)PT.Bank Rakyat Indonesia (PERSERO) Tbk, juga dapat dikategorikan tidak sehat. Karena rata-rata nilai retuen on equity bank BRI sekitar $8.33 \%$ lebih kecil dari $(<16.77 \%)$ Statistik Perbankan Indonesia. Untuk nilai Net Interest Margin (NIM) juga mengalami fluktuasi yang begitu signifikan. Pada awal periode 2019 nilai NIM cenderung rendah, namun pada akhir periode tahun 2019 nilai NIM cukup bagus dan dapat dikategorikan sehat. Namun masuk awal

\section{KESIMPULAN}

1. Pada perhitungan Return On Assets (ROA) pada PT.Bank Rakyat Indonesia (PERSERO) Tbk, Triwulan ke-I tahun 2019 sebesar $0.8 \%$ pada saat triwulan ini nilai ROA PT.Bank Rakyat Indonesia (PERSERO) Tbk, melambat terbebani oleh Danareksa sekuritas yang baru saja di akuisisi dan ada anak usaha lainnya yaitu BRI Agro dan BRI Syariah yang edang periode tahun 2020 nilai NIM kembali anjlok menjadi $2 \%$. Jika dilihat dari nilai rata-rata $\mathrm{Net}$ Interest Margin (NIM) PT.Bank Rakyat Indonesia (PERSERO) Tbk, hanya mampu menghasilkan nilai sekitar $3.83 \%$ lebih kecil dari $(<4.96 \%)$ Statistik Perbankan Indonesia. Sedangkan untuk nilai Beban Operasional terhadap Pendapatan Operasional (BOPO) PT.Bank Rakyat Indonesia (PERSERO) Tbk, dapat dikategorikan sehat. Karena nilai ratarata dari Beban Operasional terhadap Pendapatan Operasional (BOPO) sekitar 63\% lebih kecil dari $(<80.15 \%)$ Statistik Perbankan Indonesia. Semakin kecil nilai BOPO maka akan semakin efisien perusahaan tersebut dalam mengelola beban perusahaannya.

dalam tahap pembenahan dari permasalahan kredit macet. Pada triwulan ke-II nilai ROA PT.Bank Rakyat Indonesia (PERSERO) Tbk, mengalami sedikit peningkatan menjadi $1.5 \%$ dan terus meningkat pada triwulan ke-III menjadi $2.4 \%$ dan pada triwulan ke-IV menjadi $3.1 \%$. Namun pada triwulan ke-I tahun 2020 nilai ROA PT.Bank Rakyat 
Indonesia (PERSERO) Tbk, kembali menurun menjadi $0.8 \%$ dan pada triwulan ke-II nilai ROA PT.Bank Rakyat Indonesia (PERSERO) Tbk, hanya mampu mencapai nilai sebesar $1.1 \%$. Hal ini disebabkan karena pada akhir tahun 2019 munculnya virus Covid-19 yang mengguncang perekonomian dunia dan menyebabkan risiko kredit semakin tinggi. Namun jika nilai ROA PT.Bank Rakyat Indonesia (PERSERO) Tbk, dibandingkan dengan nilai ROA yang ditetapkan oleh Statistik Perbankan Indonesia maka kinerja keuangan PT.Bank Rakyat Indonesia (PERSERO) Tbk, masuk dalam kategori Tidak Sehat.

2. Pada perhitungan Return On Equity (ROE) pada PT.Bank Rakyat Indonesia (PERSERO) Tbk, menunjukan bahwa kinerja bank BRI masuk dalam kategori Tidak Sehat jika dibandingkan dengan ketetapan dari Statistik Perbankan Indonesia. Namun walaupun kinerja bank BRI terbilang tidak sehat, nilai ROE bank BRI masih mengalami peningkatan selama tahun 2019. Berdasarkan perhitungan Return On Equity (ROE) pada triwulan ke-I tahun 2019 tingkat rasionya sebesar $4 \%$ dan mengalami peningkatan pada triwulan ke-II tahun 2019 sebesar $8 \%$, pada triwulan ke-III $12 \%$ dan pada triwulan ke-IV tahun 2019 menjadi 16\%. Namun memasuki triwulan ke-I dan ke-II pada tahun 2020 ROE PT.BRI (PERSERO) Tbk mengalami penurunan yang begitu signifikan menjadi $5 \%$. Penurunan yang begitu signifikan ini disebabkan laba bersih BRI menurun karena adanya tekanan pendapatan bunga dan juga tingginya restrukturisasi kredit serta perlambatan pertumbuhan kredit.

3. Pada perhitungan Net Interest Margin (NIM) pada PT.Bank Rakyat Indonesia (PERSERO) Tbk, menunjukkan bahwa

\section{REFERENSI}

[1] R. Katriani and A. S. Dewi, "Analisis Tingkat Kesehatan Bank dan Pertumbuhan Laba pada Perusahaan Sektor Perbankan di Indonesia,” 2019. kinerja bank BRI juga masuk dalam kategori Tidak Sehat jika dibandingkan dengan Statistik Perbankan Indonesia. Walaupun terbilang tidak sehat, pada tahun 2019 PT.BRI (PERSERO) Tbk masih mampu meningkatkan nilai NIM dari triwulan ke-I tahun 2019 sebesar 2\% dan secara bertahap meningkat menjadi pada triwulan ke-II tahun 2019 menjadi sebesar 4\%, pada triwulan ke-III tahun 2019 sebesar 5\% dan pada triwulan ke-IV menjadi $7 \%$. Namun secara signifikan pada awal triwulan tahun 2020 BRI mengalami penurun kembali menjadi $2 \%$ dan pada triwulan ke-II sebesar 3\%. Hal ini disebabkan melambatnya penyaluran kredit yang berdampak pada pendapatan bunga dan pada saat bersamaan beban bunga dana simpanan yang harus dibayarkan kepada nasabah tidak mungkin dikurangi demi menjaga kecukupan likuiditas.

4. Pada perhitungan Beban Operasional terhadap Pendapatan Operasional (BOPO) pada PT.Bank Rakyat Indonesia (PERSERO) Tbk, menunjukkan bahwa kinerja bank BRI masuk dalam kategori Sehat jika dibandingkan dengan Statistik Perbankan Indonesia. Walaupun begitu, nilai BOPO PT.BRI pada tahun 2019 mengalami beberapa kali perubahan. Dan pada awal tahun 2020 nilai BOPO meningkat hingga 5\% dari akhir periode tahun 2019 dan meningkat kembali sebanyak $3 \%$ pada period eke-II tahun 2020. Nilai BOPO PT.BRI mengalami peningkatan yang cukup besar dikarenakan adanya tekanan pada pendapatan akibat restrukturisasi kredit yang masih dilakukan perseroan sejak akhir Maret 2020 guna untuk menyelamatkan UMKM yang terdampak Covid-19.

[2] D. Marlius and J. Sukma, "Analisis Tingkat Kesehatan Bank Pt. Bank Perkreditan Rakyat Jorong Kampung Tangah Pariaman Cabang Padang," 2020.

[3] M. ISWARI and others, "Analisis 
Tingkat Kesehatan Bank Pada PT. Bank Pembangunan Daerah Sumatera Barat," 2019.

[4] A. A. A. P. Mangkunegara, Evaluasi kinerja SDM. Tiga Serangkai, 2005.

[5] S. Munawir, Analisa laporan keuangan. Liberty, 2018.

[6] J. Saputra and L. Martha, "Analisis Kinerja Keuangan Dan Nilai Perusahaan, Serta Pengaruhnya Terhadap Harga Saham,” 2019.

[7] S. E. Kasmir and others, Studi Kelayakan Bisnis: Edisi Revisi. Prenada Media, 2018.

[8] S. Munawir, "Analisa Laporan Keuangan Edisi 4," Penerbit Lib. Yogyakarta, 2010.

[9] T. V. Hamolin and N. F. Nuzula, "Analisis tingkat kesehatan bank berdasarkan metode risk based bank rating (Studi pada Bank umum konvensional di Indonesia periode 2014-2016)," J. Adm. Bisnis, vol. 57, no. 1, pp. 218-226, 2018.

Dokumen :

bri.co.id. "Sejarah, Visi Misi, Struktur Organisasi PT.Bank Rakyat Indonesia (PERSERO) Tbk".

PSAK No.31 Akuntansi Perbankan

POJK No.11/POJK.03/2020 tentang

"Stimulus Perekonomian Nasional

Sebagai
Kebijakan Countercyclical

Dampak Penyebaran Corona

Virus Disease 2019 (POJK

Stimulus Dampak Covid-19)"

Peraturan Otoritas Jasa Keuangan Nomor 4/POJK.03/2016 tentang "Penilaian

Kesehatan Bank Umum"

Surat Edaran Otoritas Jasa Keuangan

Nomor 14/SEOJK.03/2017 tentang

"Penilaian Tingkat Kesehatan

Bank Umum ".

Statistik Perbankan Indonesia - Vol.17

No.4 Maret 2019

Statistik Perbankan Indonesia - Vol.17

No.7 Juni 2019

Statistik Perbankan Indonesia - Vol.17

No.10 September 2019

Statistik Perbankan Indonesia - Vol.18

No.1 Desember 2019

Statistik Perbankan Indonesia - Vol.18

No.4 Maret 2020

Statistik Perbankan Indonesia - Vol.18

No.7 Juni 2020

Undang-Undang Republik Indonesia

No.10 tahun 1998 tentang Perbankan

Undang-Undang No.20 tahun 2008

tentang Usaha Mikro, Kecil dan

Menengah (UMKM) 